Article

\title{
Applying Interactive Teaching Experience and Technology Action Puzzles in Disaster Prevention Education
}

\author{
Wen-Jye Shyr ${ }^{1, *}$, I-Min Chen ${ }^{1}$, Jing-Chuan Lee ${ }^{2}$ and Te-Jen $\mathrm{Su}^{3,4, * * 10}$ \\ 1 Department of Industrial Education and Technology, National Changhua University of Education, \\ Changhua 500, Taiwan; ylhg72103@gmail.com \\ 2 Graduate Institute of Educational Leadership and Evaluation, Southern Taiwan University of Science and \\ Technology, Tainan 710, Taiwan; jclee@stust.edu.tw \\ 3 Department of Electronics, National Kaohsiung University of Science and Technology, Kaohsiung 807, Taiwan \\ 4 Graduate Institute of Clinical Medicine, Kaohsiung Medical University, Kaohsiung 807, Taiwan \\ * Correspondence: shyrwj@cc.ncue.edu.tw (W.-J.S.); sutj@nkust.edu.tw (T.-J.S.)
}

check for

updates

Citation: Shyr, W.-J.; Chen, I-M.; Lee, J.-C.; Su, T.-J. Applying Interactive Teaching Experience and Technology Action Puzzles in Disaster Prevention Education. Sustainability 2021, 13, 4788. https://doi.org/10.3390/ su13094788

Academic Editors: Michael D.

Kickmeier-Rust, Danial Hooshyar and Nour El Mawas

Received: 5 March 2021

Accepted: 22 April 2021

Published: 24 April 2021

Publisher's Note: MDPI stays neutral with regard to jurisdictional claims in published maps and institutional affiliations.

Copyright: (C) 2021 by the authors. Licensee MDPI, Basel, Switzerland. This article is an open access article distributed under the terms and conditions of the Creative Commons Attribution (CC BY) license (https:/ / creativecommons.org/licenses/by/ $4.0 /)$.

\begin{abstract}
This study incorporated technology action puzzle and obstacle challenge activities in the course design. Using the 921 Earthquake in Taiwan as the theme, this study integrated the content of various subjects and course modules and applied information technology to present the humanistic care elements. The subjects of this study were Grade 9 students of a public middle school in central Taiwan. After the interactive operation introduction and theme film viewing, the students were divided into groups to participate in the technology action puzzle and obstacle challenge activities. Students' learning performance using smart technological tools and overall course feedback were evaluated from the aspects of building structure safety knowledge, disaster prevention and mitigation, integrated interdisciplinary thinking, and problem-solving abilities through the course planning and quasi-experimental design. The results show that (1) in terms of the learning achievement scale, the pre-test and post-test of paired samples reached statistical significance; (2) in terms of the learning response scale, the mean of the Likert five-point scale reached above 4.0; (3) the results of mediating regression analysis show that, compared with the traditional classroom teaching mode, the interactive teaching experience and technology action puzzle have a mediating effect on learning performance and overall course feedback.
\end{abstract}

Keywords: teaching models; interactive teaching; action puzzle; disaster prevention education

\section{Introduction}

The four basic concepts of disaster prevention education include (1) prevention prevails over treatment, (2) sustainable development of disaster prevention education, (3) proactive safety culture, and (4) vision of zero disasters. However, the departments dedicated to disaster prevention education are rarely seen in higher education. While many countries around the world generally agree that the promotion of disaster prevention education should start from schools, how to impart disaster prevention knowledge, cultivate a disaster prevention attitude, strengthen disaster prevention skills, or enhance disaster prevention education will be an inevitable discussion topic in the process of promoting disaster prevention education in schools at all levels.

Disaster prevention education is a necessary part of executing disaster prevention [1]. Successful disaster prevention education should include (1) allowing students to master basic disaster prevention knowledge, (2) allowing students to react appropriately and immediately to any disasters, and (3) helping school, family, and community to build a complete network to efficiently transfer information [2-4].

Relevant studies have shown that interactive learning (such as experiential education) has better learning effectiveness than traditional education (such as lessons or lectures) [5-7]. Experiential education is widely used in many kinds of lesson plans in 
order to enhance students' knowledge, skills, and learning ability [8,9]. Another study has shown that traditional classroom lectures are no longer the best teaching approach [10]. It has been demonstrated by Chin et al. that an interactive learning system used to support cultural heritage lessons helps students significantly raise their academic achievement [11]. The interactive learning system was also applied by Angel et al. in designing interactive conversation topics of machine learning and to collect students' and teachers' experiences through quantitative and qualitative indicators [12].

In addition, Reigeluth [13] stated instructional design offers principles for conceptualizing, creating, and carrying out effective instruction. It can help teachers to organize their subject matter knowledge and skill, together with their teaching knowledge and skill, into usable teaching materials. Instructional design supports foundational set of principles from educational psychology, instructional psychology, organizational psychology, and organizational psychology, and teaches best practices so that new teachers can effectively use them without needing years of training $[14,15]$.

In Taiwan, in response to the implementation of the 2019 curriculum and to help students accumulate learning experience, schools have made efforts to actively cooperate with theme museums in order to cultivate students' ability to integrate knowledge in various fields and life-long skills. The expected learning achievements can be categorized into nine qualities, namely physical and mental quality and self-improvement; systematic thinking and problem solving; planning, implementation, and innovation; symbol application and communication; scientific and technological information and media literacy; artistic knowledge and aesthetic literacy; moral practice and civic awareness; interpersonal relationships and team cooperation; and multiculturalism and international understanding.

Chen and Lin [16] indicated that better learning results in the student learning experience were achieved by using game features to change learning motivation. Wu's [17] research mentioned that exercises can attract students' attention and interest, and provided positive feedback on learning motivation. Juan and Chao [18] identified that the learning motivation of participating students showed better learning effects. Based on the abovementioned, the effect of learning through experience is clear. The method can make both the originally boring class content more interactive and the learning process more interesting. Such learning methods can not only promote learners' learning motivation, intentions, and interest but also enhance learning effectiveness.

This study aimed to analyze the learning performance and overall feedback of the students who visited the 921 Earthquake Museum of Taiwan, which belongs to the National Museum of Natural Science, through appropriate course planning. This study further explored whether the learning methods of the interactive teaching experience and technology action puzzle have mediating effects as compared with traditional classroom teaching. The course design included interactive operation introduction and film viewing in groups. Moreover, technology action devices and Q\&A items were adopted to assist each group of students in the process of obstacle guidance, interactive feedback, and problem solving and, thus, deepening their learning cognition and experience, strengthening concept integration and problem-solving ability, and enhancing disaster prevention education, team cooperation, and humanistic care.

This study distributed the learning achievement scale and learning response scale to the students. The contents of the items were reviewed by five experts and scholars in relevant fields, and they offered suggestions for modification. Validity analysis was used to analyze whether the measurement tools applied in the research process could actually measure the degree of some characteristics intended to be measured. This study adopted principal component analysis (PCA), which is one of the factor analysis methods used to extract factors. Reliability analysis is the degree of correlation between the measured data and the real data in the research process. The value for Cronbach's $\alpha$ was used to verify the internal consistency between the scales. The paired t-test method was used to analyze the learning achievement scale, and factor analysis was used to verify the reliability and validity of the learning response scale. 


\section{Literature Review}

\subsection{Disaster Prevention Education}

Normally, "Disaster Prevention Education" means that it will be easy for us to make good use of "the disaster prevention knowledge we've learned", "the disaster prevention skills we've cultivated", and "the disaster prevention attitude we've developed" if we focus on the three main lines, including "self-reaction", "values", and "learning expectations" [19-21]. The key to success of "Disaster Prevention Education" is to react positively and actively when facing a disaster. The so-called "Positive or Active Response" includes self-reaction ability, severity judgment ability, self-value, and self-responsibility, and which are absolutely the results of the learning outcomes as well as disaster prevention literacy. Moreover, according to the research conclusion of the experts, "Disaster Prevention Literacy and Attitude" is moderately correlated with "Course Design and Learning Outcomes". Therefore, this research uses the exhibition theme in the 921 Earthquake Museum of Taiwan as the course content and verifies the learning effectiveness through interactive teaching experience and technology action puzzled (skill cultivation) for further understanding of overall feedback [22].

In general, we called all the potential risks including disaster prevention, mitigation, and preparedness in disasters "Disaster Prevention Education" [23]. That is to say, "Disaster Prevention Education" is only one part of the whole disaster cycle [24]. Some scholars think that in addition to the content mentioned above, disaster recovery should be added as part of the knowledge of disaster risk $[25,26]$.

To sum up, "the correct understanding of disasters", "mastery of disaster information", and "response ability to disasters" are all closely related to disaster prevention literacy; In other words, "knowledge", "skills", and "attitude" "knowledge", "Skills", and "Attitude" are included in part of the disaster prevention literacy [27].

\subsection{Interactive Experiential Learning}

Students' learning motivation is absolutely the main factor to the promotion of the "Disaster Prevention Education", and the key factor for the success or failure of "Disaster Prevention Education" is how to enhance students" "Interests in Learning" and "Participation".

Hwang et al. [28] shows that instant feedback in learning has a positive impact on learning outcomes and learning motivation. Consequently, combining the usage of mobile devices with puzzle-solving tasks is a potential learning method. This research aims to enhance students' "Interests in Learning" and "Participation" through the situated learning that combines real-world and virtual resources.

We know that learning from experience will be positive and effective, but it will be very difficult in disaster prevention education courses. Research has shown that students are more interested in "Interactive Learning" and "Puzzle-Solving Tasks" than learning by rote [29]. Moreover, some experts indicate that "Game-Based Learning" can stimulate learning. As a consequence, the purpose of this study is to study and explore whether the disaster prevention education courses designed and develop based on game-based learning will help learners to effectively learn related disaster prevention knowledge, cultivate disaster prevention skills, and develop a disaster prevention attitude [30].

\section{Instruction Goals}

To make the learning contents more attractive, the concepts were presented in a clear and straightforward manner, combined with hands-on learning activities, which could motivate the students' learning attitude [31]. The teaching goal of this study was to plan proper "interactive teaching experience" theme content and "technology action puzzle" activities through the teaching model framework. In this way, students can experience interactive teaching and solve puzzles, and further understand the difference between their learning performance and traditional classroom learning outcomes. Finally, the overall 
feedback information regarding the course was collected as a reference for teachers to adjust the course content.

The educational connotations of this study were intended to deepen students' knowledge of the learning content in a learning environment that is based on interaction, trial, obstacle challenge, experience, and reflection. The contents of the interactive teaching experience focus on the Earthquake Engineering Education Hall, Image Recording Hall, and Disaster Prevention Education Hall of the 921 Earthquake Museum of Taiwan. The "Technology Action Puzzle" was designed using Line@, Room Escape game Holiyo, and Google Form. Through the obstacle challenge activities, the students could learn about earthquake disaster prevention knowledge, understand building structure safety, solve relevant problems with a relaxed and happy attitude, and cultivate team cooperation and humanistic care literacy.

\section{Design of the Course Content}

The content design of this study was divided into three parts. The first part was the interactive teaching experience based on the Earthquake Engineering Education Hall, Video Recording Hall, and Disaster Prevention Education Hall of the 921 Earthquake Museum of Taiwan. The second part focused on technology action puzzles and room escape challenge. The third part was the viewing of humanistic care films.

\subsection{Thematic Interactive Teaching Experience of the 921 Earthquake Museum of Taiwan 4.1.1. Earthquake Engineering Education Hall}

In this study, the selected exhibition subject courses in the Earthquake Engineering Education Hall include the following: (1) Damaged classroom preservation area classroom in the south block: shortcomings in the design and construction of traditional school buildings, such as the effects of short columns, insufficient allocation of shear walls, too large stirrup spacing, cantilever corridors, buried underground pipes in column sections, etc. (2) Shock isolation and damping components of building engineering structure system "Lead Rubber Bearing (LRB)" and "Buckling Restrained Braces (BRB)" provide explanatory and interactive experiences. (3) Explanations of local reinforcement methods for construction projects, including column expansion reinforcement, wing wall reinforcement, steel plate reinforcement, and carbon fiber reinforcement. (4) Destroyed classroom preservation area classroom in the north block-comparisons of the differences in damage conditions between the weak surface of the building structure and the upper and lower walls through which the fault line passes. (5) Explanation of the steel bar configuration of earthquakeresistant structures. (6) Subject explanation and interactive experiment of soil liquefaction. (7) Theme explanation and interactive experiment of breaking through wall surface and top floor capping. (8) Theme explanation and interactive experiment on seismic isolation and the resonance of seismic wave frequency in high and low floor building models.

\subsubsection{Image Recording Hall}

The display theme courses selected in the Video Recording Hall in this study include the following: (1) The "Trembling Moment" Unit which displays the reports of major media at home and abroad (including $\mathrm{CNN}, \mathrm{NHK}$, etc.) at the moment of earthquake occurrence. (2) "Relive 921" Unit which reviews the disaster relief reports of the 921 earthquake by major print media during the earthquake relief period and allows witnessing the miracle of life through the life corridor display method. (3) "Taiwan Family Collective Memory" Unit which, through real-life photos (including family members, schools, communities, and villages) from that time, allows visitors to know the story of post-disaster reconstruction or the reconstruction of homes and feel the strong will of human beings and demonstration of the humanistic spirit of caring for the local people. 


\subsubsection{Disaster Prevention Education Hall}

The theme courses selected by the Disaster Prevention Education Hall in this study include the following: (1) Disaster Prevention Magic Trilogy—an explanation of disaster prevention and response strategies before, during, and after an earthquake. (2) Theme explanation and interactive operation of emergency refuge backpack. (3) Thematic explanation of family disaster contingency plan. (4) Explanation and interactive operation of the earthquake-resistant plane and facade of buildings. The main purpose is to enable visitors to experience the importance of disaster prevention awareness in the process of interactive learning through exhibits, and to further introduce the correct concepts of disaster prevention to family and friends.

\subsection{Action Puzzle and Room Escape Game Learning}

This study used information media technology, technology action devices, action puzzles, and room escapes to plan courses on topics related to the display halls of the 921 Earthquake Museum of Taiwan in order to strengthen the knowledge in various fields. Moreover, to develop critical thinking skills, value judgment, and problem-solving ability, as well as to cultivate expression, communication, and teamwork, this study integrated the relevant historical facts of the 921 Earthquake into the story of "Lost Children after the Earthquake". The activity process was not only a game; instead, the course content is transformed into a real experience of obstacle challenge, resulting in deeper educational significance and humanistic care.

The instructional tools used in this study included Line@, Room Escape game Holiyo, and Google Form. During the visit, the students could use those tools to solve the puzzles and participate in obstacles challenges based on the knowledge they learned from the museum. The integration of the learning environment into a theme story could make the course content more diverse and interesting. The students could experience their learning contents, thus resulting in positive learning outcomes and feedback.

Using Google Form function and the QRcode interface as well as the designed problems and obstacle props, the students were guided to find and use the existing online resources, as based on the clues given in the scenarios, in order to make inferences, solve the puzzles, and input the answers in Google Form. The time of completion and accuracy of the answers of the obstacle challenge were calculated.

\subsection{In-Depth Reflection and Overall Feedback}

After the on-site guided tour and obstacle challenge, the students watched films and post-disaster reconstruction and shared their thoughts. Besides learning about building structure safety, disaster prevention, and mitigation, the students could also practice interdisciplinary thinking and problem-solving abilities. Moreover, the course design could inspire the students to care more about the people and things around them, cultivate their empathy, and strengthen their moral practices and civic awareness.

\section{Research Methodology}

\subsection{Participants}

This study used a quasi-experimental design with convenience sampling. The subjects were Grade 9 students of a public middle school in central Taiwan. A total of 152 students attended this course and filled out the questionnaire. The results were used as the basis for constructing a preset teaching model.

\subsection{Questionnaire Survey}

The development of both basic process skills and scientific attitude is important [32]. The teaching objective at any level is to achieve promotion such as through acquiring smart skills and solving problems, including of expecting to bring about a fundamental change in the learner. Such changes may be in the form of acquiring intellectual skills and inculcation of expecting attitudes and values. Teachers employed different approaches to help students 
to acquire knowledge, skill, and experience [33]. Shaping students' attitudes, behaviors, and motivations is necessary today, for without these broader skills and strengths, students will be unprepared for the challenges they, and their world, will face [34]. In order to determine the students' learning achievement and learning response of the study, survey scales were drawn up on the basis of similar tests found in the field literature [35]. This study distributed the pre-test, post-test, and learning response scale to the students. Among the 152 participants, 140 completed the course and the questionnaire. Thus, there were 140 valid samples (71 males and 69 females).

\subsubsection{Learning Achievement Scale}

The scale contains 20 items (see Appendix A), cover four aspects of building safety, disaster prevention knowledge, action puzzle, and in-depth reflection. The contents of the items related to professional knowledge are mainly derived from the contents of the book Earthquake Preparedness at Home-Learning about Earthquake Engineering published by the National Center for Research on Earthquake Engineering, National Applied Research Laboratories in Taiwan, which is a science manual for the promotion of disaster prevention education. In addition, the contents of the items were reviewed by five experts and scholars in relevant fields, and they offered suggestions on modification. Thus, the scale met the content validity.

\subsubsection{Learning Response Scale}

The scale contains 25 items (see Appendix B) and five dimensions of course content (cognition), interactive teaching experience (skills), technology action puzzle (skills), learning effectiveness (attitude), and overall course feedback (potential variables). Each dimension was designed with four to six items (observation variables).

\subsection{Data Processing}

The students were asked to fill out the learning achievement scale before and after participating in the course, as well as the learning response scale. The 140 valid questionnaires were coded and imported into SPSS statistical software for analysis. The paired $\mathrm{t}$-test method was used to analyze the learning achievement scale, and factor analysis was used to verify the reliability and validity of the learning response scale.

To explore the mediating mechanisms for the effectiveness of the "interactive teaching experience" and "technology action puzzle" learning methods in this course and estimate the degree and importance of the direct and indirect effects, this study used mode 80 of PROCESS macro by Hayes [36]: parallel and serial multiple mediator models. As shown in Figure 1, the model tests the predictive variable (course content, $X$ ) as well as the simultaneous effect on the parallel intermediate variables (interactive teaching experience, M1; technology action puzzle, M2), then the effect on the serial intermediate variable (learning effectiveness, M3) and, finally, the effect on the result variable (overall course feedback, Y).

All indirect effects were tested by bootstrapping analysis, which produced biascorrected bootstrap confidence intervals using 5000 bootstrap samples. When the bootstrapped upper and lower $95 \%$ confidence intervals (CI) of the indirect effects do not contain zero, it shows statistical significance. The confidence interval of the indirect effect was calculated by the following methods: replacing the original data and repeatedly sampling thousands of times, estimating the model of each sub-sample, calculating its own indirect effect, and identifying the upper and lower endpoints of the confidence interval of each model. If its confidence interval does not contain zero, the indirect effect is significantly different from zero [37].

This study tested the hypothetical model, used ordinary least squares regression to generate the model coefficients, and estimated the direct and indirect effects of the mediating mechanism. As shown in Figure 1, mode 80 was used to verify the path parameter estimates of the hypothetical hybrid serial-parallel mediation. The estimation 
of the indirect effect was obtained through a percentile bootstrapping method using 5000 bootstrap samples. Hayes and Scharkow [38] suggested that using the percentile bootstrap sampling method to test indirect effect is appropriate as it is the best compromise between statistical powers and type I errors in various inference tests.

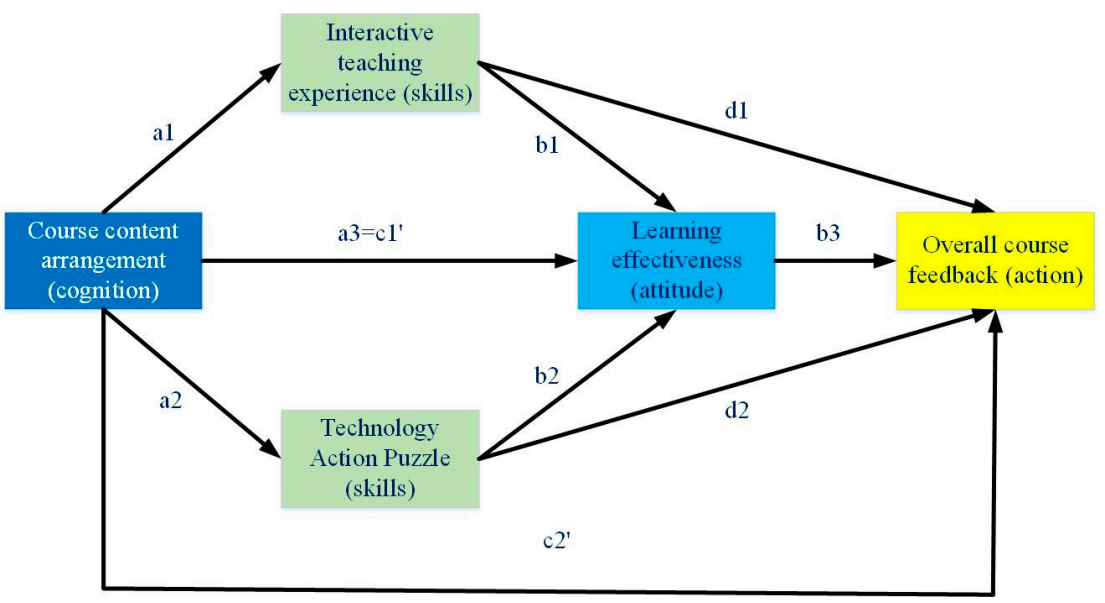

Figure 1. Path parameter estimation of mediating effect model.

\section{Results}

Prior to the course, the students took the pre-test on their knowledge about earth science, building structural safety, and earthquake prevention. After the course and experience activities, the students took the post-test and filled out the learning response scale to evaluate the course model structure, activity design, implementation effect, and overall feedback.

\subsection{Paired $t$-Test}

Regarding the learning achievement scale, Table 1 shows the results of the pre-test and post-test. As seen, the average score of the pre-test is 56.71 and that of the post-test is 75.64. The paired samples of the pre-test and post-test have reached statistical significance $(t=15.840)$. This suggests that through the interactive teaching experience and technology action puzzle, the students can effectively improve their learning effectiveness regarding building structure safety, disaster prevention, and mitigation knowledge.

Table 1. Comparison of post-test versus pre-test by paired sample statistics.

\begin{tabular}{ccccccc}
\hline Tests & N & Mean & Std. Deviation & $\begin{array}{c}\text { Post-Test- } \\
\text { Pre-Test }\end{array}$ & $\mathbf{t}$ & \\
\hline Post-test & 140 & 75.64 & 15.741 & 18.929 & 15.84 & $* * *$ \\
Pre-test & 140 & 56.71 & 19.98 & & & \\
*** $p<0.001$. & & & &
\end{tabular}

\subsection{Reliability and Validity Test}

This study conducted the exploratory factor analysis on 25 items in the learning response scale. Five factors were extracted, and those factors with eigenvalues greater than 1.00 were selected. Then, the factors with factor loading greater than 0.45 were extracted by varimax orthogonal rotation. After three rounds of factor analysis, items No. 22 to 24 were deleted. The results show that the KMO value of the scale is 0.962 , which indicates good reliability [39]. The $\chi^{2}$ value of the Bartlett [40] sphericity test is 3467.534 , which has reached a significant level. This study suggests that the items of the learning response scale have common factors which are suitable for factor analysis. The results of factor analysis show that $82.684 \%$ of the total variation can be explained, which is significantly more than $50 \%$ and indicates good validity. According to the criteria of validity analysis, 
the scale used in this study has good factor validity. Then, the reliability of the scale was further analyzed. The reliability coefficient was used to test the internal consistency of Cronbach's $\alpha$ test scale, and the analysis results show that the Cronbach's $\alpha$ value of each factor component scale is between 0.897 and 0.953, and the Cronbach's $\alpha$ value of the overall scale is 0.973 . This suggests that the internal consistency of this scale is good. According to the reliability analysis criteria, the scale used in this study has high reliability. The results are summarized in Table 2 .

Table 2. Summary of items and validity and reliability analysis of research tools.

\begin{tabular}{|c|c|c|c|c|c|c|c|}
\hline Dimension & Item & CITC & $\begin{array}{l}\text { Item Analysis } \\
\qquad \begin{array}{l}\alpha \text { Value after } \\
\text { Deletion of This Item }\end{array}\end{array}$ & Eigenvalue & $\begin{array}{l}\text { Validity Analysis } \\
\text { Cumulative Variance } \\
\text { Explained \% }\end{array}$ & $\begin{array}{c}\text { Factor } \\
\text { Loadings }\end{array}$ & $\begin{array}{l}\text { Reliability } \\
\text { Analysis } \\
\text { Cronbach's } \alpha\end{array}$ \\
\hline \multirow{4}{*}{$\begin{array}{l}\text { Course } \\
\text { content }\end{array}$} & 1 & 0.724 & 0.972 & 5.009 & 22.768 & 0.743 & \multirow{4}{*}{0.897} \\
\hline & 2 & 0.767 & 0.972 & & & 0.706 & \\
\hline & 3 & 0.750 & 0.972 & & & 0.665 & \\
\hline & 4 & 0.708 & 0.972 & & & 0.704 & \\
\hline \multirow{4}{*}{$\begin{array}{l}\text { Interactive } \\
\text { teaching } \\
\text { experience }\end{array}$} & 5 & 0.781 & 0.972 & 3.745 & 39.791 & 0.757 & \multirow{4}{*}{0.939} \\
\hline & 6 & 0.776 & 0.972 & & & 0.775 & \\
\hline & 7 & 0.757 & 0.972 & & & 0.776 & \\
\hline & 8 & 0.777 & 0.972 & & & 0.764 & \\
\hline \multirow{4}{*}{$\begin{array}{l}\text { Science and } \\
\text { technology } \\
\text { action puzzle }\end{array}$} & 9 & 0.787 & 0.971 & 3.703 & 56.624 & 0.718 & \multirow{4}{*}{0.95} \\
\hline & 10 & 0.790 & 0.971 & & & 0.799 & \\
\hline & 11 & 0.814 & 0.971 & & & 0.766 & \\
\hline & 12 & 0.781 & 0.972 & & & 0.795 & \\
\hline \multirow{6}{*}{$\begin{array}{c}\text { Learning } \\
\text { effectiveness }\end{array}$} & 13 & 0.811 & 0.971 & 3.154 & 70.961 & 0.769 & \multirow{6}{*}{0.953} \\
\hline & 14 & 0.754 & 0.972 & & & 0.761 & \\
\hline & 15 & 0.748 & 0.972 & & & 0.772 & \\
\hline & 16 & 0.835 & 0.971 & & & 0.752 & \\
\hline & 17 & 0.770 & 0.972 & & & 0.792 & \\
\hline & 18 & 0.802 & 0.971 & & & 0.763 & \\
\hline \multirow{4}{*}{$\begin{array}{l}\text { Overall } \\
\text { course } \\
\text { feedback }\end{array}$} & 19 & 0.813 & 0.971 & 2.579 & 82.684 & 0.522 & \multirow{4}{*}{0.913} \\
\hline & 20 & 0.791 & 0.971 & & & 0.751 & \\
\hline & 21 & 0.786 & 0.971 & & & 0.771 & \\
\hline & 25 & 0.763 & 0.972 & & & 0.498 & \\
\hline & & & Total scale & & & & 0.973 \\
\hline
\end{tabular}

Note: KMO of factor analysis of the course learning scale $=0.962$; Bartlett sphericity test $\chi^{2}=3467.534(p<0.001)$.

\subsection{Correlation and Descriptive Statistical Analysis}

In order to ensure the correlation between the mediating mechanism and the variables of the curriculum model, as constructed in this study, Pearson correlation analysis was carried out. The correlation and descriptive statistics of the research variables, as shown in Table 3, indicate that there is significant correlation $(p<0.001)$ between all variables (including prediction variables, parallel and serial intermediate variables, result variables, etc.), where $X$ is positively correlated with M1, M2, and M3, and M3 is also positively correlated with Y. 
Table 3. Correlation and descriptive statistics of variables.

\begin{tabular}{cccccccc}
\hline Research Variable & M & SD & X & M1 & M2 & M3 & Y \\
\hline X-Course content (cognition) & 4.188 & 0.658 & 1 & & & & \\
M1-Interactive teaching experience (skill) & 4.036 & 0.771 & $0.723^{* * *}$ & 1 & & \\
M2-Technology action puzzle (skill) & 4.170 & 0.755 & $0.712^{* * *}$ & $0.673^{* * *}$ & 1 & \\
M3-Learning effectiveness (attitude emotion) & 4.099 & 0.768 & $0.696^{* * *}$ & $0.693^{* * *}$ & $0.723^{* * *}$ & 1 \\
Y-Overall course feedback & 4.143 & 0.738 & $0.772^{* * *}$ & $0.757^{* * *}$ & $0.766^{* * *}$ & $0.746^{* * *}$ & $1^{1}$ \\
\hline
\end{tabular}

Note: $\mathrm{N}=140 ;{ }^{* * *} p<0.001$.

\section{Discussions}

Based on the students' learning achievement, the learning response was explored. The present study explored the learning performance and the overall feedback of the students who visited the 921 Earthquake Museum of Taiwan was investigated in this study. This study further explored whether the learning methods of the interactive teaching experience and technology action puzzle have mediating effects as compared with traditional classroom teaching.

The cognitive-affective theory of learning [41] conceptualizes new types of learning in a framework combining cognitive and affective aspects. The control value theory of achievement attitude refers to learning achievement-related attitude for examining the affective factors [42]. In the literature [43,44], assumptions of achievement attitude are transcribed into an experimental study design and are investigated concerning their motivation and satisfaction. In line with this, the students' learning achievement and learning response that contains course content (cognition), learning effectiveness (attitude), and overall course feedback (potential variables) are intensely explored by applying the interactive teaching experience and technology action puzzle approach in the 921 Earthquake Museum of Taiwan.

\subsection{Parameter Estimation of Mediating Effect Model}

This study used the course content $(X)$ as the independent variable, the overseas course feedback $(\mathrm{Y})$ as the result variable, and the interactive teaching experience (M1), technology action puzzle (M2), and learning effectiveness (M3) as the mediating variables, as shown in Table 4. First, the course content $(X)$ has significant positive predictive effect on interactive teaching experience (M1) $(\mathrm{a} 1=0.848, t=12.300, p<0.001)$, and its predictive interpretation variance is $52.3 \%$; the course content $(X)$ has significant positive predictive effect on the technology action puzzle (M2) $(\mathrm{a} 1=0.818, t=11.915, p<0.001)$, and its predictive interpretation variance is $50.7 \%$. Course content $(X)$, interactive teaching experience (M1), and technology action puzzle (M2) have significant positive predictive effects on learning effectiveness (M3) ( $\mathrm{a} 3=0.270, t=2.713, p<0.01$; $\mathrm{B} 1=0.274, t=3.403$, $p<0.01 ; \mathrm{B} 2=0.379, t=4.690, p<0.001$ ). The variance of predictive interpretation is $62.1 \%$. Finally, course content $(X)$, interactive teaching experience (M1), technology action puzzle (M2), and learning effectiveness (M3) also have significant positive predictive effects on the overseas course feedback $(\mathrm{Y})\left(\mathrm{c} 2^{\prime}=0.295, t=3.656, p<0.001\right)$; B3 $=0.185, t=2.723, p<0.01$; $\mathrm{D} 1=0.241, t=3.630, p<0.001 ; \mathrm{D} 2=0.264, t=3.835, p<0.001)$. The variance of predictive interpretation is $74.5 \%$.

\subsection{Test of Each Effect of the Mediating Mechanism}

This study used PROCESS 3.5 mode 80 to test the overall, direct, and indirect effects, as shown in Table 5 . First, the course content $(X)$ has significant positive overall effect $(\mathrm{c} 2=$ $0.866, t=14.263, p<0.001)$ on the overall course feedback $(\mathrm{Y})$; second, the course content $(\mathrm{X})$ also has significant positive direct effect $\left(\mathrm{c} 2^{\prime}=0.295, t=3.656, p<0.001\right)$ on the overall course feedback $(\mathrm{Y})$, that is, the course content has significant positive direct effect ( $\mathrm{c}^{\prime}{ }^{\prime}=$ $0.295, t=3.656, p<0.001)$ on the overall course feedback (Y) after adding the mediating variables, such as the interactive teaching experience (M1), technology action puzzle (M2), 
and learning effectiveness (M3). These results show that this model has partial mediation, and its strength of mediation $\left(\mathrm{c} 2-\mathrm{c} 2^{\prime}\right) / \mathrm{c} 2$ is $65.9 \%$.

Table 4. Regression coefficient and model summary for mediator regression analysis of curriculum learning effectiveness.

\begin{tabular}{|c|c|c|c|c|c|c|c|c|c|c|c|c|c|c|c|c|}
\hline \multirow{2}{*}{$\begin{array}{l}\text { Result Variable } \\
\text { Predictive } \\
\text { Variable }\end{array}$} & \multicolumn{4}{|c|}{ M1 } & \multicolumn{4}{|c|}{ M2 } & \multicolumn{4}{|c|}{ M3 } & \multicolumn{4}{|c|}{$\mathbf{Y}$} \\
\hline & \multicolumn{3}{|c|}{ Coefficient } & \multicolumn{2}{|l|}{$p$} & \multicolumn{2}{|c|}{ Coefficientt } & \multicolumn{2}{|l|}{$p$} & \multicolumn{2}{|c|}{ Coefficient } & \multicolumn{2}{|l|}{$p$} & \multicolumn{2}{|c|}{ Coefficient } & \multirow{2}{*}{$\begin{array}{c}p \\
0.724\end{array}$} \\
\hline Constant term & $\mathrm{i}_{\mathrm{M} 1}$ & 0.485 & 1.659 & 0.099 & $\mathrm{i}_{\mathrm{M} 2}$ & 0.746 & 2.565 & 0.011 & $\mathrm{i}_{\mathrm{M} 3}$ & 0.281 & 1.046 & 0.297 & $\mathrm{i}_{Y}$ & 0.075 & 0.354 & \\
\hline$X$ & $\mathrm{a}_{1}$ & 0.848 & 12.300 & 0.000 & $\mathrm{a}_{2}$ & 0.818 & 11.915 & 0.000 & a3 & 0.270 & 2.713 & 0.008 & $c 2^{\prime}$ & 0.295 & 3.656 & 0.000 \\
\hline M3 & & & & & & & & & & & & & $\mathrm{b}_{3}$ & 0.185 & 2.723 & 0.007 \\
\hline M1 & & & & & & & & & $b_{1}$ & 0.274 & 3.403 & 0.001 & $\mathrm{~d}_{1}$ & 0.241 & 3.630 & 0.000 \\
\hline M2 & & & & & & & & & $b_{2}$ & 0.379 & 4.690 & 0.000 & $\mathrm{~d}_{2}$ & 0.264 & 3.835 & 0.000 \\
\hline Model summary & \multicolumn{4}{|c|}{$\begin{array}{c}\mathrm{R}^{2}=0.523 \\
8)=151.296(p\end{array}$} & \multicolumn{4}{|c|}{$\begin{array}{c}\mathrm{R}^{2}=0.507 \\
8)=141.969(p\end{array}$} & \multicolumn{4}{|c|}{$\begin{array}{r}\mathrm{R}^{2}=0.621 \\
38)=74.247(p\end{array}$} & \multicolumn{4}{|c|}{$\begin{array}{r}\mathrm{R}^{2}=0.745 \\
35)=98.484(p\end{array}$} \\
\hline
\end{tabular}

Note: Course content arrangement $(\mathrm{X})$, Interactive teaching experience (M1), Technology action puzzle (M2), Learning effectiveness (M3), Overall course feedback $(\mathrm{Y})$

Table 5. The overall, direct, and indirect effects of mediated regression analysis on the learning effectiveness of courses.

\begin{tabular}{|c|c|c|c|c|c|c|}
\hline \multirow[b]{2}{*}{ Category (Coefficient) } & \multirow[b]{2}{*}{ Effect Path } & \multirow[b]{2}{*}{ Effect Size } & \multirow[b]{2}{*}{$t$ Value } & \multirow[b]{2}{*}{$p$ Value } & \multicolumn{2}{|c|}{ Bootstrapping 95\% Trust Interval } \\
\hline & & & & & Lower Limit (LLCI) & Upper Limit (ULCI) \\
\hline Overall effect (c2) & $X \rightarrow Y$ & 0.866 & 14.263 & 0.000 & 0.671 & 0.932 \\
\hline Direct effect $\left(c 2^{\prime}\right)$ & $\mathrm{X} \rightarrow \mathrm{Y}$ & 0.295 & 3.656 & 0.000 & 0.136 & 0.455 \\
\hline Aggregate indirect effect & $X \rightarrow Y$ & 0.570 & & & 0.361 & 0.872 \\
\hline Indirect Effect (a1*d1) & $\mathrm{X} \rightarrow \mathrm{M}_{1} \rightarrow \mathrm{Y}$ & 0.204 & & & 0.054 & 0.361 \\
\hline Indirect Effect $(\mathrm{a} 2 * \mathrm{~d} 2)$ & $\mathrm{X} \rightarrow \mathrm{M}_{2} \rightarrow \mathrm{Y}$ & 0.216 & & & 0.017 & 0.364 \\
\hline Indirect Effect $(\mathrm{a} 3$ *b3) & $\mathrm{X} \rightarrow \mathrm{M} \rightarrow \mathrm{Y}$ & 0.050 & & & -0.008 & 0.234 \\
\hline Indirect Effects $\left(\mathrm{a} 1^{*} \mathrm{~b} 1{ }^{*} \mathrm{~b} 3\right)$ & $\mathrm{X} \rightarrow \mathrm{M} \rightarrow \mathrm{M}_{3} \rightarrow \mathrm{Y}$ & 0.043 & & & 0.001 & 0.155 \\
\hline Indirect Effect $(\mathrm{a} 2 * \mathrm{~b} 2 * \mathrm{~b} 3)$ & $\mathrm{X} \rightarrow \mathrm{M}_{2} \rightarrow \mathrm{M}_{3} \rightarrow \mathrm{Y}$ & 0.057 & & & 0.001 & 0.239 \\
\hline
\end{tabular}

The course content $(X)$ has significant positive total indirect effects $\left(\sum a{ }^{*} b i=0.509\right.$, Boot $\mathrm{CI}=0.361,0.872)$ on the overall course feedback $(Y)$ through the mediating variables, such as the interactive teaching experience (M1), technology action puzzle (M2), and learning effectiveness (M3).

The test of the specific indirect effects of each path shows that (1) course content $(X)$ has significant indirect effects $(\mathrm{a} 1 * \mathrm{~d} 1=0.204$, Boot $\mathrm{CI}=0.054,0.361)$ on the overseas course feedback $(\mathrm{Y})$ through the interactive teaching experience (M1), and its mediating effect intensity $\left(\mathrm{a} 1^{*} \mathrm{~d} 1 / \mathrm{c} 2\right)$ reaches $23.6 \%$; $(2)$ course content $(\mathrm{X})$ has a significant indirect effect $(\mathrm{a} 2 * \mathrm{~d} 2=0.216$, Boot $\mathrm{CI}=0.017,0.364)$ on the overseas course feedback $(\mathrm{Y})$ through the mediation of the technology action puzzle (M2), and its mediating effect intensity $(a 2 * d 2 / c 2)$ is $25.0 \%$; $(3)$ course content $(X)$ has a significant indirect effect $\left(a 1^{*} b 1 * b 3=0.043\right.$, Boot $\mathrm{CI}=0.001,0.155)$ on the overseas course feedback $(\mathrm{Y})$ through the interactive teaching experience (M1) and L = learning effectiveness (M3) in sequence, and its mediating effect intensity $\left(\mathrm{a} 1^{*} \mathrm{~b} 1^{*} \mathrm{~b} 3 / \mathrm{c} 2\right)$ is only $5.0 \%$; and $(4)$ course content $(X)$ has a significant indirect effect $\left(a 2^{*} b 2 * b 3=0.057\right.$, Boot $\left.C I=0.001,0.239\right)$ on the overseas course feedback $(Y)$ through the mediation of the technology action puzzle (M2) and learning effectiveness (M3) in sequence, and its mediating effect intensity $\left(a 2^{*} b 2 * b 3 / c 2\right)$ is only $6.6 \%$.

The standardized regression coefficients paths of Figure 2 show that the mediating mechanism of the course designed in this study has four significant indirect effects, of which the two stronger paths are (1) $\mathrm{X} \rightarrow \mathrm{M} 1 \rightarrow \mathrm{Y}$ and (2) $\mathrm{X} \rightarrow \mathrm{M} 2 \rightarrow \mathrm{Y}$, respectively, while the two weaker paths are (1) $\mathrm{X} \rightarrow \mathrm{M} 1 \rightarrow \mathrm{M} 3 \rightarrow \mathrm{Y}$ and (2) $\mathrm{X} \rightarrow \mathrm{M} 2 \rightarrow \mathrm{M} 3 \rightarrow \mathrm{Y}$.

The overall evaluation results of this study show that (1) course design and obstacle challenge activities can achieve the teaching objectives; (2) the learning methods of "interactive experience" and "team obstacle challenge" can improve learning willingness 
and interest; and (3) students agree that using smart technological tools for learning can effectively improve learning outcomes.

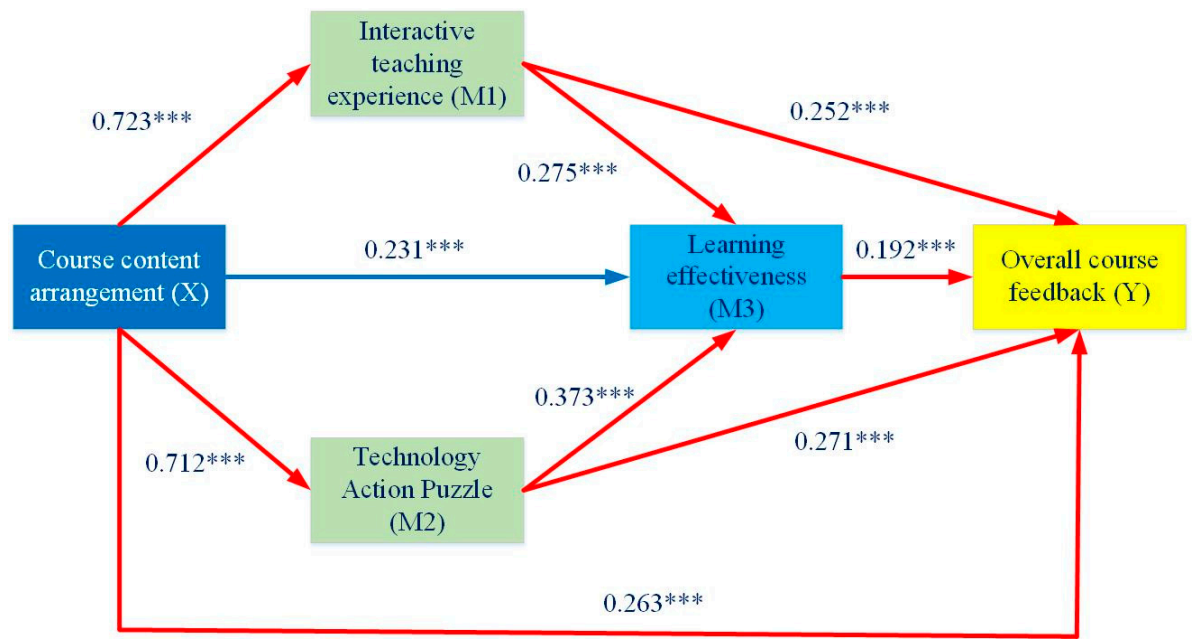

Figure 2. Analysis results of mediating effect model of curriculum learning effect (note: the path coefficient in the figure is estimated as a standardized regression coefficient). $\left.{ }^{* * *} p<0.001\right)$.

\section{Conclusions}

This study designed a course on disaster prevention by integrating interactive teaching experience and technology action puzzles, and evaluated the student's learning effectiveness and feedback. The results show that (1) regarding the learning achievement scale, the paired samples of the pre-test and post-test reached statistical significance, (2) the correlation and descriptive statistics of the research variables indicate that there is significant correlation between all variables (including prediction variables, parallel and serial intermediate variables, result variables, etc.), (3) the course content has significant positive total indirect effects on the overall course feedback through the mediating variables, such as the interactive teaching experience, technology action puzzles, and learning effectiveness.

The conclusions of this study are summarized as follows: (1) the students have good understanding of the building structure safety, disaster prevention, and mitigation knowledge, (2) the students gave positive feedback on the overall course design and obstacle challenge activities; and (3) compared with the traditional classroom teaching methods, the learning methods of "interactive teaching experience" and "technology action puzzles" have some mediating effects on the learning results and the overall course feedback. This conclusion is consistent with the results of related studies in literature review.

This study used the exhibition of the 921 Earthquake Museum of Taiwan as the main content as well as theme films to evaluate the learning outcomes and feedback of the students. The main contribution of the course design are as follows: (1) students can learn about the concepts of building structure safety, disaster prevention, and mitigation through the "interactive teaching experience"; (2) students can strengthen their interdisciplinary thinking and problem-solving ability through the "technology action puzzle"; and (3) students can realize humanistic care and cultivate disaster prevention literacy.

However, since this study had a quasi-experimental design for secondary education students, the content mainly focused on engineering education and disaster prevention education, and these essential differences should be considered when designing other courses or courses for different age groups. Therefore, further studies can be conducted on learning methods, such as the "interactive teaching experience" and "technology action puzzle" for in-depth discussion. 
Author Contributions: All authors contributed meaningfully to this study. W.-J.S. and I.-M.C.research topic; W.-J.S., I.-M.C., J.-C.L. and T.-J.S.- data acquisition and analysis; W.-J.S. and T.J.S.-methodology support; W.-J.S., J.-C.L. and T.-J.S.- -original draft preparation; W.-J.S. and T.J.S.- -writing review and editing. All authors have read and agreed to the published version of the manuscript.

Funding: This research received no external funding.

Institutional Review Board Statement: Not applicable.

Informed Consent Statement: Not applicable.

Data Availability Statement: Not applicable.

Conflicts of Interest: The authors declare no conflict of interest.

\section{Appendix A. Learning Achievement Scale \\ [Building safety aspects]}

1.( ) In order to ensure the building structure safety and improve the seismic resistance, what should the angle of the stirrup (the steel bar around the main reinforcement) hook be during construction? (A) 0 degree (B) 135 degrees (C) 100 degrees (D) any angle

2.( ) Which of the following statements on "the building structure safety of residences" is false? (A) In the building structure, the seismic resistance is good when the column stirrup spacing is between 10 and $15 \mathrm{~cm}$. (B) During an earthquake, the building structures with tuned mass dampers (commonly known as damping balls) are safe. (C) In order to increase the efficient use of space, according to the actual need, additions can be built on the top floors or partition walls can be removed. (D) During an earthquake, the building structures with seismic isolation devices are safe.

3.( ) Which of the following is not a seismic resistance measure for home space? (A) Baffles can be installed in front of open shelves to prevent things from falling off the shelves. (B) Heavy objects can be placed high to avoid being kicked and tripped during escape. (C) Supporting rods (floor to top) can be installed above cabinets or other objects with appropriate heights can be inserted, so as to prop up ceilings. (D) Explosion-proof heat insulation film can be affixed to avoid glass fracturing and scattering.

4.( ) Which of the following is "not" the reason why buildings with steel-reinforced concrete (SRC) structures collapse or sink? (A) Strong typhoons (B) Resonance effect caused by ground vibration frequency close to natural frequency of buildings (C) Seismic forces (D) Faults are dislocated and buildings are located on fault lines

5.( ) Which of the following is the way to improve the seismic resistance of building structures? (A) Structural reinforcement (B) Seismic isolation method (C) Seismic reduction method (D) All of the above

\section{[Disaster prevention knowledge aspects]}

6. ( ) Which of the following concepts about emergency kit preparation is true? (A) As basic necessities, the more drinking water and food are prepared, the more secured it will be. (B) They should be locked out of reach of children to avoid accidents. (C) They should be centrally placed at easily accessible locations, so that all family members can easily access them. (D) The drinking water and food in backpacks should be replaced regularly. 7.( ) Which of the following items should not be put in an emergency kit? (A) Multi-function flashlight (B) Fire extinguisher (C) Aluminum foil blanket (D) Cash

8.( ) Which of the following statements on earthquake preparedness at ordinary times is "false"? (A) All emergency kits should contain the emergency shelter supplies needed by the whole family to meet the escape needs. (B) Appropriate hardware fittings should be used at ordinary times to secure bookcases or other tall furniture in the home. (C) More than two emergency escape routes should be planned in the home. (D) Do not take elevators to escape during an earthquake. 
9. ( ) Which of the following building shapes is safe in an earthquake if the total heights of

the buildings are the same? (A)

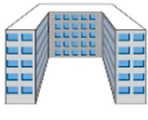

(B)

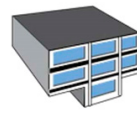

(C)

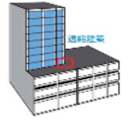

(D)

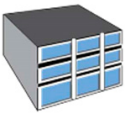

10.( ) Which of the following behaviors is wrong when taking refuge outside during an earthquake? (A) On the street, move to open areas and watch for falling objects or glass fragments. (B) At the beach, get away from shorelines as quickly as possible for higher ground as soon as the shaking stops. (C) During driving, brake cars immediately, stay beside cars after flameout and pay attention to the surrounding safety. (D) In the mountains, stay away from the steep slopes or cliffs, to avoid the risk of rockfalls.

\section{[Action puzzle aspects]}

11.( ) Which of the following cloud interfaces "have no" automatic response mechanisms when designing mobile riddling for the learning field? (A) LINE Official Account (B) Google window (C) Google meet (D) Holiyo.

12.( ) Which of the following information map interfaces can be used to inquire the settlement development and distribution in early Taiwan (for example, around 1900)? (A) Administrative Map of Taiwan (B) Great Universal Geographic Map (C) PMG Field Survey of Taiwan (D) Da Ming Hunyi Tu

13. ( ) According to the "trifid cipher table" below, if "221113113311" means "GOOD", how to express "GJJH", the symbol of Gunag-Jheng Junior High School? (A) 221223223222 (B) 221323323221 (C) 331221131211 (D) 123123123123

\begin{tabular}{|c|c|c|c|c|c|c|c|c|c|c|c|}
\hline & & 1 & & & & 2 & & & & 3 & \\
\hline 1 & L & E & O & & N & A & R & & D & V & I \\
\hline 2 & C & B & F & & G & H & J & & K & M & P \\
\hline 3 & Q & S & T & & U & W & X & & Y & Z & / \\
\hline & 1 & 2 & 3 & & 1 & 2 & 3 & & 1 & 2 & 3 \\
\hline
\end{tabular}

14. ( ) According to the diagram below (please view from the right arrow), what is the information conveyed by the English bookmark? (A) Seismic waveform of 921 Earthquake (B) Psychic trauma caused by 921 Earthquake (C) Ground damage caused by 921 Earthquake (D) Scale of 921 Earthquake

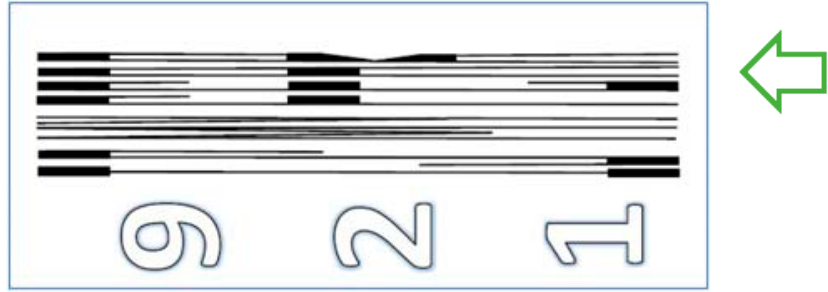

15.( ) In using the mobile phone to solve the Holiyo riddling, in the case of any problem that cannot be solved, how to switch to another question? (A) Press the previous page key on the mobile phone (B) Press the escape key at the lower right of Holiyo (C) Press the confirm key at the lower left of Holiyo (D) Leave the interface and re-enter

\section{[In-depth reflectionaspects]}

16.( ) Which of the following items is "not" the response of abandoned children after an earthquake? (A) Depressed, with a lot of negative attitude (B) Suppressed, forcing 
themselves to grow (C) Missing, miss their families on festive occasions more than ever (D) Happy, enjoy their independence

17. ( ) Which of the following methods is "inappropriate" to help abandoned children to get through their pains? (A) Suppress to avoids attitude catharsis (B) Guide them to express attitude (C) Care about them and accompany them to grow up (D) Be empathetic and help them face their pains

18.( ) There are many charities around us to provide the necessary assistance in disasters. Which of the following organizations providing social assistance in 921 Earthquake? (A) Tzu Chi Foundation (B) Dharma Drum Mountain Social Welfare and Charity Foundation (C) Child Welfare League Foundation (D) All of the above.

19.( ) Which of the following "is not" the actions taken by the government after 921 Earthquake? (A) Set up the 921 reconstruction committee (B) Set up the 921 Earthquake Museum of Taiwan to keep records (C) Set up an earthquake prediction center to predict earthquakes (D) Strengthen building structure codes

20. ( ) Our attitudes to major disasters should be (A) Play safe to avoid being involved (B) Work together to deal with it (C) Downplay with normal attitudes (D) Ecological law of "the survival of the fittest"

Appendix B. Learning Response Scale

\begin{tabular}{|c|c|c|c|c|c|c|}
\hline & & 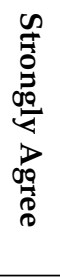 & $\underset{0}{\stackrel{D}{0}}$ & T. & 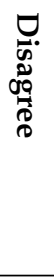 & 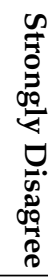 \\
\hline & & 5 & 4 & 3 & 2 & 1 \\
\hline $\begin{array}{l}\text { 1. The course of "Knowledge on Building Safety and Disaster Prevention and } \\
\text { Reduction" is based on daily life. }\end{array}$ & & 5 & 4 & 3 & 2 & 1 \\
\hline $\begin{array}{l}\text { 2. The course of "Instruction on Interactive Operation of Teaching Aids" is mean- } \\
\text { ingful. }\end{array}$ & --------- & 5 & 4 & 3 & 2 & 1 \\
\hline 3. It is interesting to apply "Smart Phones" to staged learning. & ----------- & 5 & 4 & 3 & 2 & 1 \\
\hline 4. The course of "Film Appreciation and Interpretation" is vivid and touching. & ------------ & 5 & 4 & 3 & 2 & 1 \\
\hline 5.In the course, I can participate in theme guides and interpretations carefully. & ----------- & 5 & 4 & 3 & 2 & 1 \\
\hline $\begin{array}{l}\text { 6. In the course, I can participate in instructions on interactive operation of teaching } \\
\text { aids carefully. }\end{array}$ & --- & 5 & 4 & 3 & 2 & 1 \\
\hline 7. In the course, I can understand the meanings of theme guides and interpretations. & ------- & 5 & 4 & 3 & 2 & 1 \\
\hline $\begin{array}{l}\text { 8. In the course, I can understand the purposes or principles of instructions on } \\
\text { interactive operation of teaching aids. }\end{array}$ & & 5 & 4 & 3 & 2 & 1 \\
\hline $\begin{array}{l}\text { 9. In the process of staged learning, I can use the smart phone to enter situations } \\
\text { with my classmates. }\end{array}$ & & 5 & 4 & 3 & 2 & 1 \\
\hline $\begin{array}{l}\text { 10. In the process of staged learning, I can use the smart phone to carry out mobile } \\
\text { riddling with my classmates. }\end{array}$ & - & 5 & 4 & 3 & 2 & 1 \\
\hline $\begin{array}{l}\text { 11. In the process of staged learning, I can use the smart phone to escape from } \\
\text { rooms with my classmates. }\end{array}$ & & 5 & 4 & 3 & 2 & 1 \\
\hline $\begin{array}{l}\text { 12. In the process of staged learning, I can use the smart phone to find or confirm } \\
\text { answers with my classmates. }\end{array}$ & & 5 & 4 & 3 & 2 & 1 \\
\hline $\begin{array}{l}\text { 13. The course of instruction on interactive operation may improve my willingness } \\
\text { to learn. }\end{array}$ & 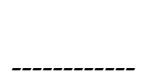 & 5 & 4 & 3 & 2 & 1 \\
\hline 14. It is interesting to learn by the method of instruction on interactive operation. & & 5 & 4 & 3 & 2 & 1 \\
\hline 15. The instruction on interactive operation may help me to learn further. & & 5 & 4 & 3 & 2 & 1 \\
\hline 16. The course of smart phone riddling may improve my willingness to learn. & & 5 & 4 & 3 & 2 & 1 \\
\hline 17. It is interesting to learn by the method of smart phone riddling. & & 5 & 4 & 3 & 2 & 1 \\
\hline 18. The smart phone riddling may help me to learn further. & & 5 & 4 & 3 & 2 & 1 \\
\hline $\begin{array}{l}\text { 19. Participating in the film appreciation and interpretation of this course can } \\
\text { remind me to learn to reflect on myself. }\end{array}$ & -------------- & 5 & 4 & 3 & 2 & 1 \\
\hline
\end{tabular}




\begin{tabular}{|c|c|c|c|c|c|c|}
\hline $\begin{array}{l}\text { 20. Participating in the film appreciation and interpretation of this course can } \\
\text { remind me to learn to respect others. }\end{array}$ & ------------ & 5 & 4 & 3 & 2 & 1 \\
\hline $\begin{array}{l}\text { 21. Participating in the film appreciation and interpretation of this course can } \\
\text { remind me to learn to care for the society. }\end{array}$ & & 5 & 4 & 3 & 2 & 1 \\
\hline $\begin{array}{l}\text { 22. Participating in this series of courses made me realize the importance of } \\
\text { teamwork. } \\
\text { 23. Participating in this series of courses helped me to improve my abilities of }\end{array}$ & & 5 & 4 & 3 & 2 & 1 \\
\hline $\begin{array}{l}\text { integrated thinking and problem solving. } \\
24 \text {. If there is an opportunity in the future, I will apply the knowledge or skills }\end{array}$ & & 5 & 4 & 3 & 2 & 1 \\
\hline learned in this course to my life. & ---------- & 5 & 4 & 3 & 2 & 1 \\
\hline $\begin{array}{l}\text { 25. If there is an opportunity in the future, I will share the knowledge or skills } \\
\text { learned in this course with my family or friends. }\end{array}$ & & 5 & 4 & 3 & 2 & 1 \\
\hline
\end{tabular}

\section{References}

1. Sherrieb, K.; Louis, C.A.; Pfefferbaum, R.L.; Pfefferbaum, B.; Diab, E.; Norris, F.H. Assessing community resilience on the US coast using school principals as key informants. Int. J. Disaster Risk Reduct. 2012, 2, 6-15. [CrossRef]

2. Johnson, V.A.; Ronan, K.R.; Johnston, D.M.; Peace, R. Evaluations of disaster education programs for children: A methodological review. Int. J. Disaster Risk Reduct. 2014, 9, 107-123. [CrossRef]

3. Wilson, J.H.; Ryan, R.G. Professor-student rapport scale: Six items predict student outcomes. Teach. Psychol. 2013, 40, 130-133. [CrossRef]

4. Chou, J.S.; Yang, K.H.; Ren, T.C. Ex-post evaluation of preparedness education in disaster prevention mitigation and response Int. J. Disaster Risk Reduct. 2015, 12, 188-201. [CrossRef]

5. Chen, C.Y.; Yu, K.H.; Chen, M.Y. Planning of professional teacher-training program for disaster prevention education and executing efficiency evaluation. Disaster Prev. Manag. 2012, 21, 608-623. [CrossRef]

6. Frankenberg, E.; Sikoki, B.; Sumantri, C.; Suriastini, W.; Thomas, D. Education vulnerability and resilience after a natural disaster. Ecol. Soc. 2013, 18, 16. [CrossRef] [PubMed]

7. Oktari, R.S.; Shiwaku, K.; Munadi, K.; Shaw, R. A conceptual model of a school-community collaborative network in enhancing coastal community resilience in Banda Aceh Indonesia. Int. J. Disaster Risk Reduct. 2015, 12, 300-310. [CrossRef]

8. Tsai, M.H.; Chang, Y.L.; Shiau, J.S.; Wang, S.M. Exploring the effects of a serious game-based learning package for disaster prevention education: The case of Battle of Flooding Protection. Int. J. Disaster Risk Reduct. 2020, 43, 101393. [CrossRef]

9. Mulyasari, F.; Takeuchi, Y.; Shaw, R. Implementation Tools for Disaster Education, Community, Environment and Disaster Risk Management; Shaw, R., Ed.; Emerald Publications: Singapore, 2011; pp. 137-151.

10. Sakurai, A.; Sato, T. Promoting education for disaster resilience and the Sendai framework for disaster risk reduction. J. Disaster Res. 2016, 11, 402-412. [CrossRef]

11. Chin, K.Y.; Lee, K.F.; Chen, Y.L. Using an interactive ubiquitous learning system to enhance authentic learning experiences in a cultural heritage course. Interact. Learn. Environ. 2018, 26, 444-459. [CrossRef]

12. Ángel, M.T.; Ana, C.M.; Juan-Antonio, F.M. Teaching machine learning in robotics interactively: The case of reinforcement learning with Lego ${ }^{\circledR}$ Mindstorms. Interact. Learn. Environ. 2019, 27, 293-306.

13. Reigeluth, C. Instructional-Design Theories and Models: A New Paradigm of Instructional Theory; Reigeluth, C.M., Ed.; Lawrence Erlbaum: New York, NY, USA, 1999; Volume II.

14. Dick, W.; Carey, L.; Carey, J.O. The Systematic Design of Instruction; Longman: New York, NY, USA, 2004.

15. Hardré, P.L.; Ge, X.; Thomas, M.K. Toward a model of development for instructional design expertise. Educ. Technol. 2005, 45, 53-57.

16. Chen, H.R.; Lin, Y.S. An examination of digital game-based situated learning applied to Chinese language poetry education. Technol. Pedagog. Educ. 2016, 25, 171-186. [CrossRef]

17. $\mathrm{Wu}, \mathrm{T} . \mathrm{T}$. Improving the effectiveness of English vocabulary review by integrating ARCS with mobile game-based learning. J. Comput. Assist. Learn. 2018, 34, 315-323. [CrossRef]

18. Juan, Y.K.; Chao, T.W. Game-based learning for green building education. Sustainability 2015, 7, 5592-5608. [CrossRef]

19. Sakurai, A.; Sato, T.; Murayama, Y. Impact evaluation of a school-based disaster education program in a city affected by the 2011 great East Japan earthquake and tsunami disaster. Int. J. Disaster Risk Reduct. 2020, 47, 101632. [CrossRef]

20. Chung, S.C.; Yen, C.J. Disaster prevention literacy among school administrators and teachers: A study on the plan for disaster prevention and campus network deployment and experiment in Taiwan. J. Life Sci. 2016, 10, 203-214.

21. Mileti, D.S.; Darlington, J.D. The role of searching in shaping reactions to earthquake risk information. Soc. Probl. 1997, 44, 89-103. [CrossRef]

22. Whitney, D.J.; Lindell, M.K.; Nguyen, H.H.D. Earthquake beliefs and adoption of seismic hazard adjustments. Risk Anal. 2004, 24, 87-102. [CrossRef] [PubMed]

23. Becker, J.S.; Paton, D.; Johnston, D.M.; Ronan, K.R. A model of household preparedness for earthquakes: How individuals make meaning of earthquake information and how this influences preparedness. Nat. Hazards 2012, 64, 107-137. [CrossRef] 
24. Djonko-Moore, C.M.; Leonard, J.; Holifield, Q.; Bailey, E.B.; Almughyirah, S.M. Using culturally relevant experiential education to enhance urban children's knowledge and engagement in science. J. Exp. Educ. 2018, 41, 137-153. [CrossRef]

25. Cajanding, R.J. Effects of a structured discharge planning program on perceived functional status cardiac self-efficacy patient satisfaction, and unexpected hospital revisits among Filipino cardiac patients: A randomized controlled study. J. Cardiovasc. Nurs. 2017, 32, 67-77. [CrossRef] [PubMed]

26. Felder, R.M.; Silverman, L.K. Learning and teaching styles in engineering education. J. Eng. Educ. 1988, 78, 674-681.

27. Shyr, W.J. Integrating bio-energy laboratory activities into a junior high school classroom. Int. J. Eng. Educ. 2011, 27, 585-590.

28. Hwang, G.J.; Wu, P.H.; Ke, H.R. An interactive concept map approach to supporting mobile learning activities for natural science courses. Comput. Educ. 2011, 57, 2272-2280. [CrossRef]

29. Admiraal, W.; Huizenga, J.; Akkerman, S.; Dam, G. The concept of flow in collaborative game-based learning. Comput. Hum. Behav. 2011, 27, 1185-1194. [CrossRef]

30. Haring, P.; Chakinska, D.; Ritterfield, U. Understanding Serious Gaming: A Psychological Perspective, Improving Learning and Motivation through Educational Games: Multidisciplinary Approaches; IGI Global: Hershey, PA, USA, 2011; pp. 413-430.

31. Korwin, R.; Do, J.R.E. Hands-on technology-based activities enhance learning by reinforcing cognitive knowledge and retention. J. Technol. Educ. 1990, 1, 26-33. [CrossRef]

32. Opulencia, L.M. Correlates of science achievement among grade-VI pupils in selected elementary schools, San Francisco District, Division of San Pablo City. Laguna State Polytech. Univ. 2011.

33. Tebabal, A.; Kahssay, G. The effects of student-centered approach in improving students' graphical interpretation skills and conceptual understanding of kinematical motion. Lat. Am. J. Phys. Educ. 2011, 5, 374-381.

34. Miller, R.K. Building on Math and Science: The New Essential Skills for the 21st-Century Engineer. Res. Technol. Manag. 2017, 60, 53-56. [CrossRef]

35. National Center for Research on Earthquake Engineering, National Applied Research Laboratories in Taiwan. Earthquake Preparedness at Home-Learning about Earthquake Engineering. Available online: http://www.ncree.org/safehome/pdf/ITEE_ All.pdf (accessed on 12 March 2021).

36. Hayes, A.F. The PROCESS Macro for SPSS, SAS, and R (Version 3.5). Available online: http:/ /www.processmacro.org/download. html (accessed on 12 January 2021).

37. Hayes, A.F. Introduction to Mediation Moderation and Conditional Process Analysis, 2nd ed.; The Guilford Press: New York, NY, USA, 2018.

38. Hayes, A.F.; Scharkow, M. The relative trustworthiness of inferential tests of the indirect effect in statistical mediation analysis. Psychol. Sci. 2013, 24, 1918-1927. [CrossRef] [PubMed]

39. Kaiser, H.F. An index of factorial simplicity. Psychometrika 1974, 39, 31-36. [CrossRef]

40. Bartlett, M.S. The effect of standardization on a Chi-square approximation in factor analysis. Biometrika 1951, 38, 337-344.

41. Moreno, R.; Mayer, R. Interactive multimodal learning environments: Special issue on interactive learning environments: Contemporary issues and trends. Educ. Psychol. Rev. 2007, 19, 309-326. [CrossRef]

42. Pekrun, R. The control-value theory of achievement emotions: Assumptions, corollaries, and implications for educational research and practice. Educ. Psychol. Rev. 2006, 18, 315-341. [CrossRef]

43. Sommer, M.; Ritzhaupt, A. Impact of the flipped classroom on learner achievement and satisfaction in an undergraduate technology literacy course. J. Inf. Technol. Educ. Res. 2018, 17, 159-182. [CrossRef]

44. Alamri, M.M. Students' learning achievement performance and satisfaction in a flipped classroom in Saudi Arabia. Int. J. Technol. Enhanc. Learn. 2019, 11, 103-119. [CrossRef] 